\title{
CINIA
}

The $2^{\text {nd }}$ Conference on Innovation and Industrial Applications (CINIA 2016)

\section{Kajian Traffic Separation Scheme di Wilayah Perairan Teluk Bintuni}

\author{
Yeyes Mulyadi1, Taufik Fajar Nugroho2, Kriyo Sambodho1 \& Emmy Pratiwi3 \\ 1Dosen Teknik Kelautan, Fakultas Teknologi Kelautan, Institut Teknologi Sepuluh Nopember \\ 2Dosen Teknik Sistem Perkapalan, Fakultas Teknologi Kelautan, Institut Teknologi Sepuluh Nopember \\ 3Mahasiswa Program Doktoral Teknologi Kelautan, Institut Teknologi Sepuluh Nopember \\ yeyesmulyadi@gmail.com
}

\begin{abstract}
Abstrak
Pengembangan fasilitas bangunan laut seperti platform, subsea pipeline, subsea cable, maupun mini FLNG di wilayah perairan di teluk Bintuni mengakibatkan penyempitan area olah gerak kapal-kapal yang beroperasi di wilayah tersebut. Pengembangan infrastruktur tersebut juga berpengaruh terhadap meningkatnya lalu lintas kunjungan kapal. Hal ini dapat berdampak pada peningkatan resiko tabrakan, baik tabrakan antar kapal, tabrakan antara kapal dengan platform, maupun kemungkinan terjadi kapal kandas. Untuk itu, pada studi ini dilakukan Kajian Traffic Separation Scheme (TSS), dengan tiga alternatif desain shipping lane. Kajian ini menekankan pada perbandingan tingkat resiko kecelakaan yang terjadi pada masing-masing desain shipping lane, serta mitigasi yang direkomendasikan. Kata kunci: Traffic Separation Scheme, Teluk Bintuni Shipping lane.
\end{abstract}

\section{PENDAhuluan}

Teluk Bintuni daerah di Papua Barat seperti pada Gambar 1 merupakan salah satu daerah yang berpotensi dalam pengembangan industri gas alam. Gas alam ditemukan di Bintuni Teluk pada tahun 1994 dengan cadangan sekitar 14 trillion cubic feet (tcf). Sumur gas di Teluk Bintuni dieksploitasi dengan mendirikan bangunan berupa platform yang terletak di beberapa lokasi di Teluk Bintuni. Dengan menggunakan pipa bawah laut, gas diangkut ke kilang yang berada di selatan Teluk Bintuni.

Selain aktifitas eksploitasi gas alam, petrochemical plant juga akan dibangun di Teluk Bintuni yang rencananya akan mulai beroperasi sekitar tahun 2017 dan 2018. Peningkatan dalam bidang industri dan pembangunan di Teluk Bintuni di masa depan menyebabkan kenaikan juga pada kepadatan lalu lintas kapal di area tersebut. Untuk menjaga keselamatan kapalkapal yang melewati alur, maka kajian mengenai Traffic Separation Schemes (TSS) diperlukan untuk menentukan alur pelayaran di Teluk Bintuni.

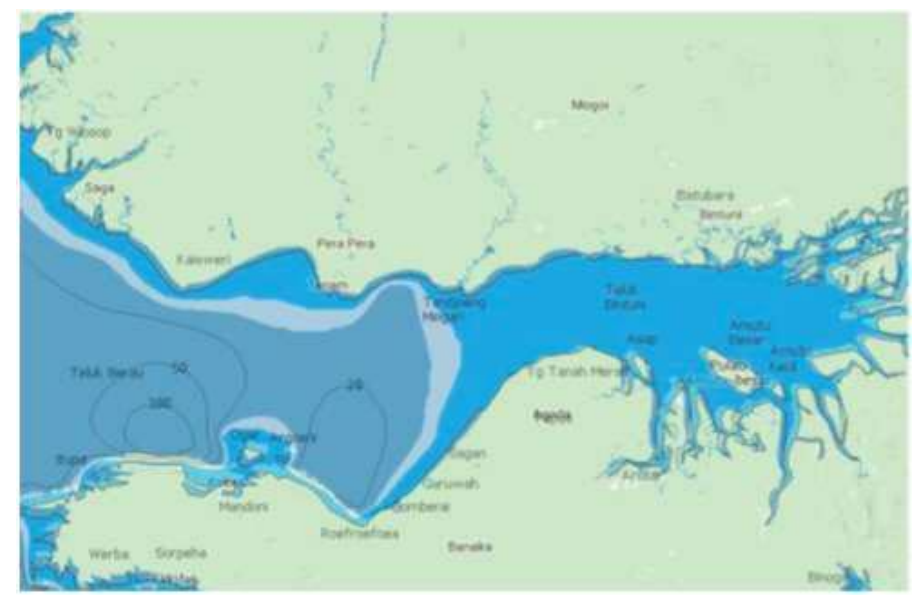

Gambar 1 Area Teluk Bintuni

Kajian TSS di area Teluk Bintuni ini bertujuan untuk menentukan alternatif alur lalu lintas kapal sehingga dapat menjamin keselamatan kapal-kapal yang lewat terhadap fasilitas platform yang telah ada disana. Dalam menentukan alternatif alur lalu lintas kapal ini berkaitan dengan beberapa hal, diantaranya:

- Studi mengenai risiko kapal terhadap rencana instalasi platform dan pipa gas bawah laut

- Studi mengenai risiko kapal terhadap kondisi geografik seperti kedalaman laut, arus laut, dan angin.

- Studi mengenai proyeksi pembangunan kapal yang melewati Teluk Bintuni. 
Terdapat tiga skenario yang dibuat dalam skema ini. Semua potensi dan masalah dari masing-masing skenario akan dipelajari. Ketiga skenario alternatif alur tersebut adalah: Alur utara, Alur tengah dan Alur selatan.

\section{TINJAUAN PUSTAKA}

2.1. Konsep Traffic Separation Schemes (TSS)

Alur pelayaran adalah laut yang memiliki kedalaman dan lebar yang dianggap aman untuk kapal melewati area tersebut dan bebas dari bahaya atau hazard. Traffic Separation Scheme adalah suatu skema routing yang dimaksudkan untuk memisahkan lalu lintas kapal pada arah yang berlawanan dengan menyediaan alur tertentu. Konsep TSS untuk Teluk Bintuni ini didasarkan pada:

1. Kondisi perairan seperti lebar alur, arus laut, angin dan gelombang.

2. Dimensi kapal.

3. Densitas lalu lintas kapal.

4. Hazard

5. Karakteristik kapal.

6. Alur tertentu seperti alur untuk kapal ikan dan alur untuk aktifitas gas dan minyak.

7. Setiap alur yang biasa digunakan untuk navigasional atau aktifitas perminyakan dan gas internasional.

\subsection{Analisis Frekuensi Ship to Ship collision}

Model yang digunakan pada analisis frekuensi tubrukan kapal dengan kapal ini menggunakan konsep yang dikembangkan oleh Mulyadi [1] dan [2]. Model ini terdiri dari dua parameter utama yaitu jumlah kandidat kapal-kapal yang bertabrakan $(\mathrm{Na})$ dan probabilitas penyebab tabrakan $(P c)$. Na dihitung berdasarkan kondisi geografik dan lalu lintas kapal yang melewati beberapa skenario jalur pelayaran yang direncanakan untuk TSS di Teluk Bintuni. Pc diperoleh dengan pendekatan berdasarkan beberapa referensi yang tersedia dan sesuai untuk diterapkan di Teluk Bintuni.

$$
N d=N a x P c
$$

Jumlah kandidat kapal-kapal yang bertabrakan $(\mathrm{Na})$ diperoleh dengan mengalikan beberapa parameter dan kelas kapal yang berbeda di setiap segmen dan zona kritis. Oleh karena itu, jumlah kandidat kapal-kapal yang bertabrakan head-on di segmen kritis pada alur pelayaran tertentu sesuai kelas $i$ dan xona $z$, dapat ditunjukkan dengan formula berikut:

$$
N A_{i z}=L_{c z} \sum_{i, j} \frac{V_{i}^{(1)}+V_{j}^{(2)}}{V_{i}^{(1)} V_{j}^{(2)}} Q_{i}^{(1)} Q_{J}^{(1)} V_{i}^{(1)} P_{e z}^{(1)} P_{e z}^{(2)} P_{q z} \Delta T
$$

Dimana $V i$ dan $V j$ adalah kecepatan kapal $i$ dan kapal $j$, Q adalah jumlah kapal dengan kelas $i$ atau $j$, pada alur pelayaran 1 atau 2, sedangkan $P$ menunjukkan probabilitas kapal yang melewati encounter segment dari alur pelayaran 1 atau 2 di zona z. $P g z$ didapatkan dari perkalian antara kemungkinan kapal berada di segmen bahaya L pada area alur pelayaran $P_{l z}$ dan probabilitas kapal di jarak kritisnya side-by-side $P_{b z}$.

Pada umumnya, layout dari alur pelayaran di Teluk Bintuni dapat dikategorikan kedalam 2 tipe: crossing dan paraller fairways. Gambar 2 menunjukkan pertemuan kapal di crossing dan paraller fairway pada suatu alur.

\subsection{Analisis Frekuensi Tubrukan Kapal dengan Platform (Powered Vessel Collision)}

Tabrakan yang melibatkan passing vessel termasuk hal yang jarang terjadi (sekitar $4 \%$ dari semua laporan tabrakan) namun berpotensi menyebabkan kerusakan yang cukup parah. Penyebab utama dari tabrakan ini adalah adanya kegagaan dalam watchkeeping akibat kesalahan manusia atau faktor teknis dan tidak memperhatikan adanya platform pada area tertentu. Tabrakan ini biasa disebut dengan powered vessel collision.

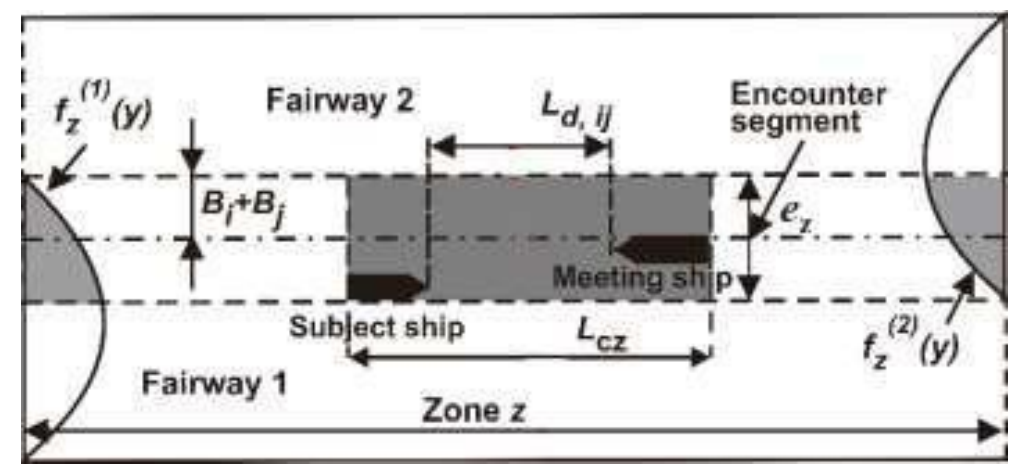

Gambar 2 Ship-Ship Encounter pada Critical Crossing Fairway Area

Ketika ada suatu platform yang dipasang di offshore, platform tersebut menjadi penghalang bagi navigasi dan pasti mempengaruhi pola lalu lintas di area tersebut. Kapal-kapal menjadi berhati-hati terhadap adanya platform, sehingga kapalkapal akan mulai untuk merencanakan rute untuk menghindarinya. Hal ini menimbulkan potensi adanya kapal-kapal yang menubruk platform dengan tipe tubrukan powered vessel collision. 
Frekuensi tubrukan tiap tahun $(F c p)$ dihitung untuk tiap alur pelayaran yang melewati platform dengan persamaan berikut (Spouge, 1999).

$F_{c p}=N \times F_{d} \times P_{1} \times P_{2} \times P_{3}$

Dimana $\mathrm{N}$ adalah total kapal di alur tiap tahun, Fd (Gambar 3) adalah proporsi kapal di alur yang menuju langsung ke platform, P1 adalah peluang kegagalan dalam berlayar di alur yang direncakanan, P2 adalah kegagalan dalam watchkeeping dan P3 merupakan peluang platform atau kapal lain untuk memberikan alert kepada kapal tersebut untuk menghindar.

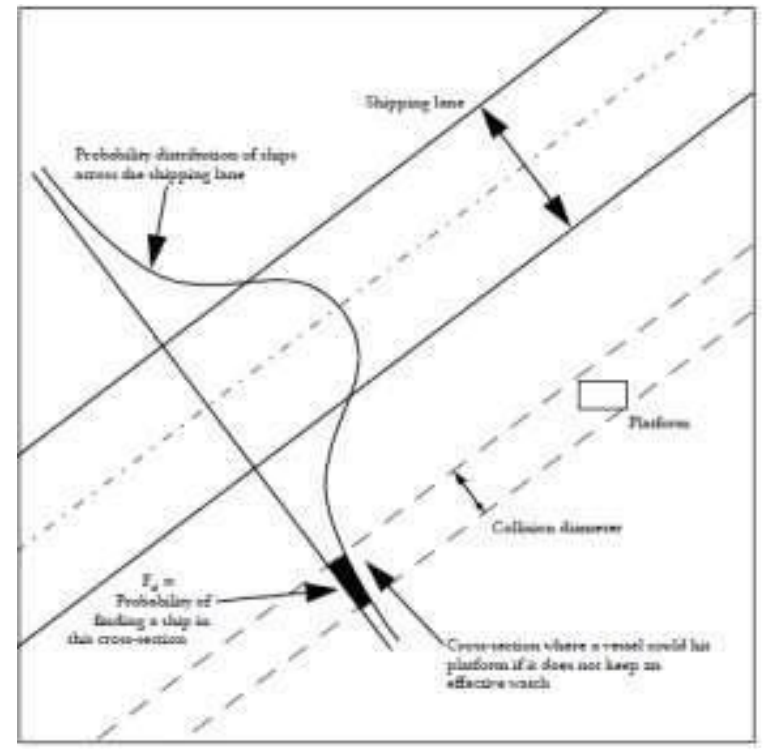

Gambar 3 Geometri Powered passing vessel (Spouge, 1999)

Frekuensi tubrukan sebanding dengan ukuran dari kapal dan platform. Gabungan dari kedua ukuran ini disebut dengan Collision Diamater. Collision diameter didefinisikan sebagai lebar dari alur dimana kapal dapat menubruk platform seperti yang terlihat pada Gambar 2.10 [3].

Lebar collision diameter ini merupakan lebar platform yang terihat dan lebar kapal yang melewati alur menuju platform tersebut. Berikut ini adalah persamaan untuk collision diameter :

$D=W_{A}+B$

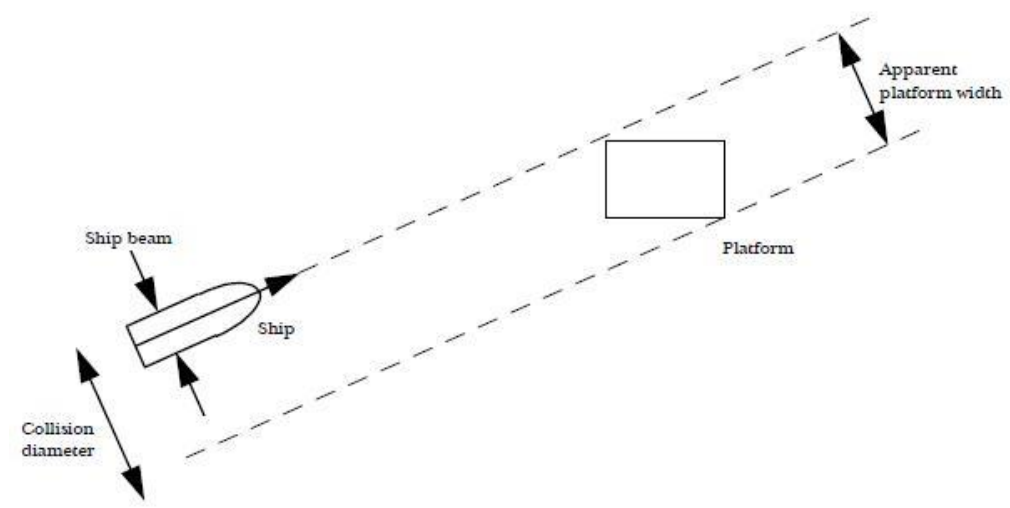

Gambar 4 Collision Diameter (Spouge, 1999)

Peluang $\left(F_{d}\right)$ kapal mengalami tubrukan dengan platform adalah sebanding dengan distribusi kepadatan kapal yang melintasi alur seperti pada collision diameter.

$$
F_{d}=D \times f(A)
$$

$f(A)$ adalah kemungkinan kepadatan pada center dari objek dan A merupakan jarak dari objek ke garis tengah alur pada titik terdekat yang dijangkau. Untuk distribusi normal, peluang kepadatannya adalah :

$$
F(A)=\frac{1}{2 \sigma} \exp \frac{-k^{2}}{2}
$$


dimana:

$\sigma \quad=$ standard deviasi dari distribusi lalu lintas yang melewati alur

$k=A / \sigma$ atau jumlah dari standard deviasi dari objek dari pusat alur

\subsection{Analisis Frekuensi Tubrukan Kapal dengan Platform (Drifting Passing Vessel Collision)}

Tipe tubrukan lain yang mungkin terjadi adalah drifting collision. Drifting collision ini terjadi ketika kapal mengalami breakdown (propulsi atau steering) dan drift akibat terbawa angin atau gelombang menuju ke platform. Kecepatan $d r i f t$ kapal ini relatif rendah sehingga masih memungkinkan untuk melakukan evakuasi pencegahan menuju ke platfrom. Kapal yang menyimpang dari alur dan menabrak dengan platform terdekat dapat terjadi apabila dalam kondisi berikut ini :

- Kapal mengalami kerusakan pada sistem propulsinya

- Arah angin yang dapat membuat kapal menyimpang dari alur dan menuju ke objek

- Ada kapal lain yang mencoba untuk menarik kapal tersebut tetapi tidak berhasil objek

- Kapal mengalami kegagalan dalam memperbaiki kerusakan didalam kapal itu sendiri sebelum kapal menjangkau

Skenario yang dikembangkan untuk drifting passing vessel collision seperti pada Gambar 5. Persamaan matematis untuk drifting collision ini sebagai berikut:

$F_{c p}=N_{b} \times F_{b} \times P_{W} \times D / B L$
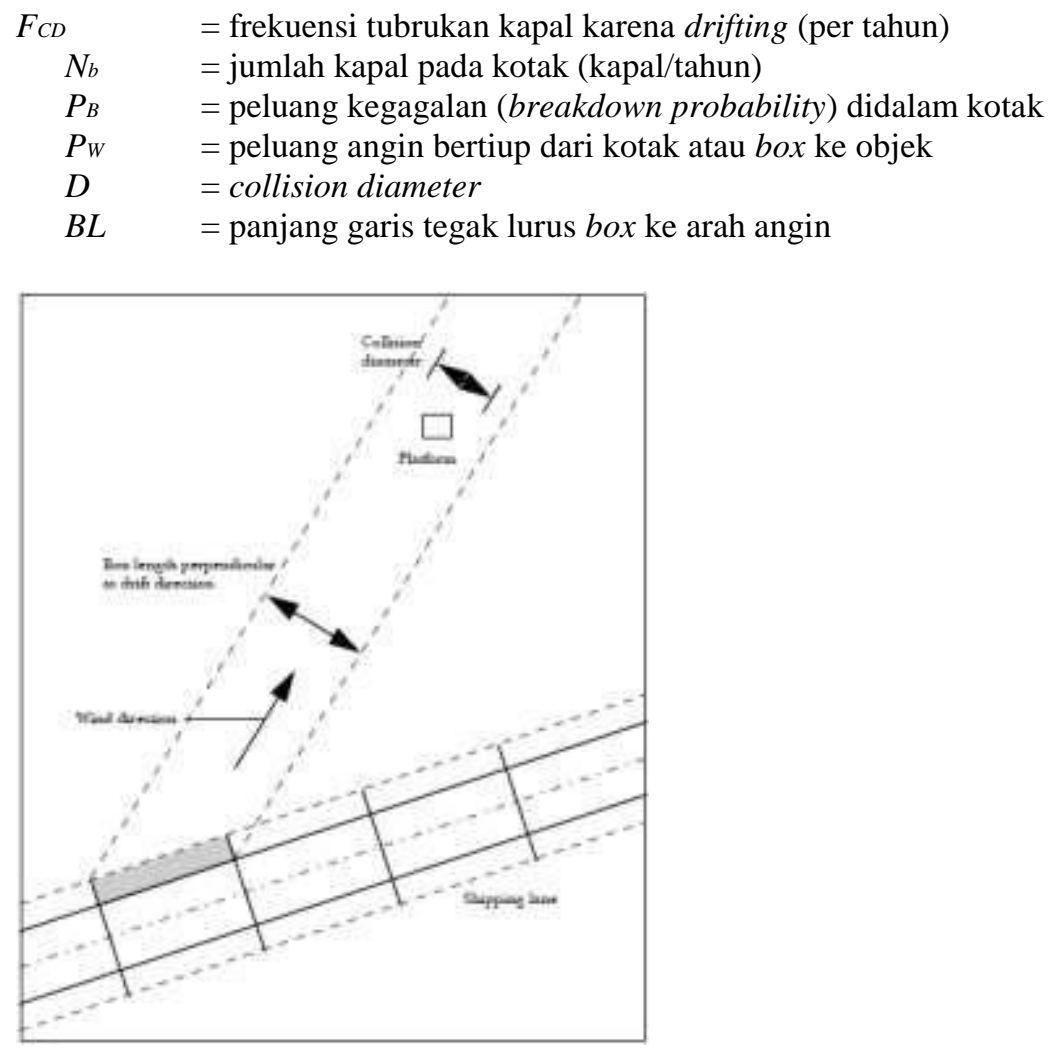

Gambar 5 Drifting Collision Geometry (Spouge, 1999)

\section{METODE PENELITIAN}

Kajian mengenai traffic separatin scheme di Teluk Bintuni ini dilakukan dengan mempertimbangkan keselamatan lalu lintas kapal-kapal yang biasa beroperasi di area tersebut. Alur yang direncanakan didasarkan pada beberapa hal seperti kondisi gegrafis disekitar area Teluk Bintuni, kondisi perairan, dan juga densitas kapal serta data kapal-kapal. Analisis frekuensi tubrukan antar kapal dan kapal terhadap platform dengan tipe tubrukan powered vessel collision dan drifting collision dilakukan untuk memastikan bahwa beberapa alternatif alur yang dirancang akan tetap aman di masa mendatang. Analisis frekuensi tubrukan antar kapal menggunakan metode berdasarkan Mulyadi, et al., (2014), sedangkan untuk powered vessel collision dan drifting collision dihitung dengan quantitative risk assessment dari DNV[3].

\section{HASIL DAN PEMBAHASAN}

\subsection{Skema Rencana Alur Pelayaran}

Berdasarkan beberapa pertimbangan yang telah disebutkan pada Bab II mengenai TSS, maka Gambar 6 berikut menampilkan semua alternatif skema alur pelayaran yang direncanakan. 


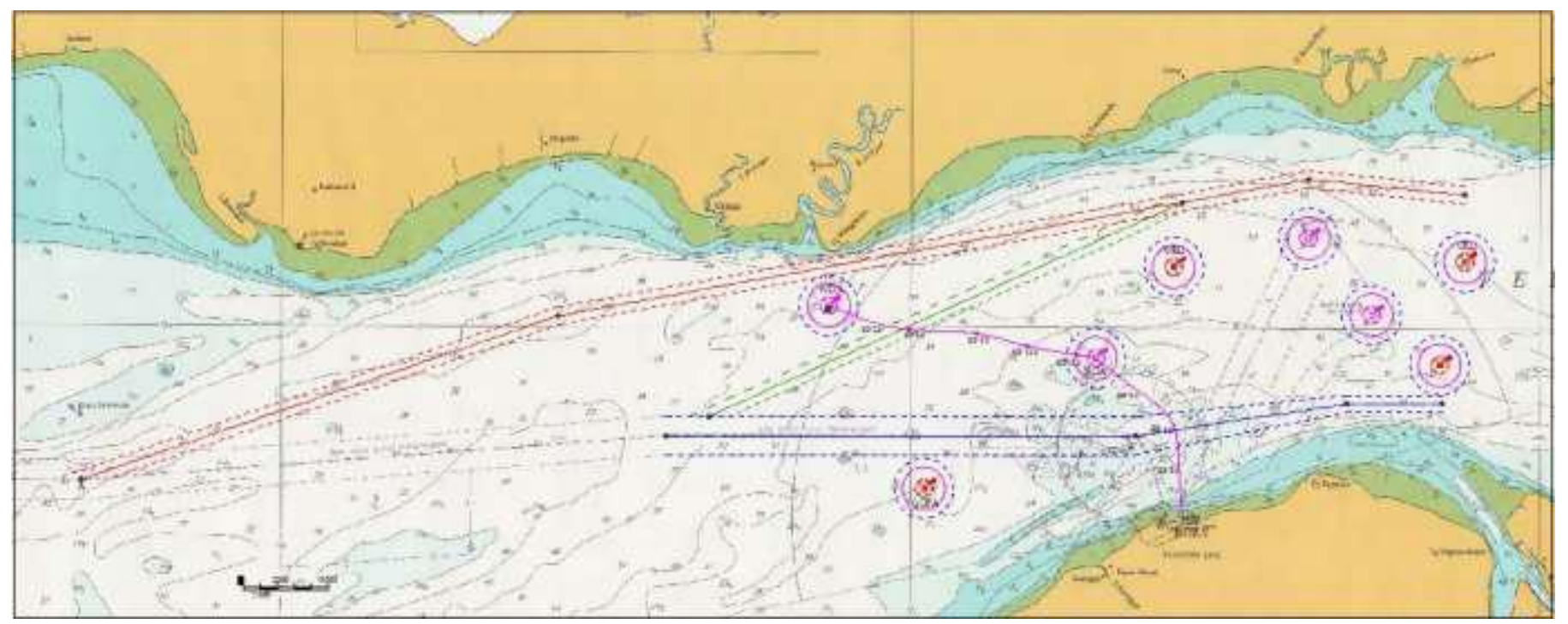

Gambar 6 Semua Skema Rencana Alur Pelayaran

\subsection{Ship to Ship Collision}

\subsubsection{Causation Probability untuk Ship to Ship Collision}

Pada studi ini, probabilitas kapal berada di situasi error dapat diperkirakan dengan menggunakan metode Bayesian networks. Model Bayesian Network ini dikembangkan dengan memodifikasi network fragment yang dikembangkan oleh Det Norske Veritas (DNV). Bayesian Network harus mencerminkan karaterisitik spesifik mengenai lokasi studi, dimana pada permasalahan studi ini berlokasi di Teluk Bintuni. Diasumsikan bahwa tabrakan di Teluk Bintuni disebabkan oleh kapal yang kehilangan kontrol. Faktor utama yang berkontribusi terhadap losing control ini adalah kondisi cuaca, alat deteksi navigasi, kemampuan manusia, penandaan buoy, komunikasi antar kapal, kondisi geografis, dan kegagalan steering. Pc yang didapatkan dari model Bayesian network untuk diterapkan di Teluk Bintuni ini dapat dilihat pada Gambar 7 berikut.

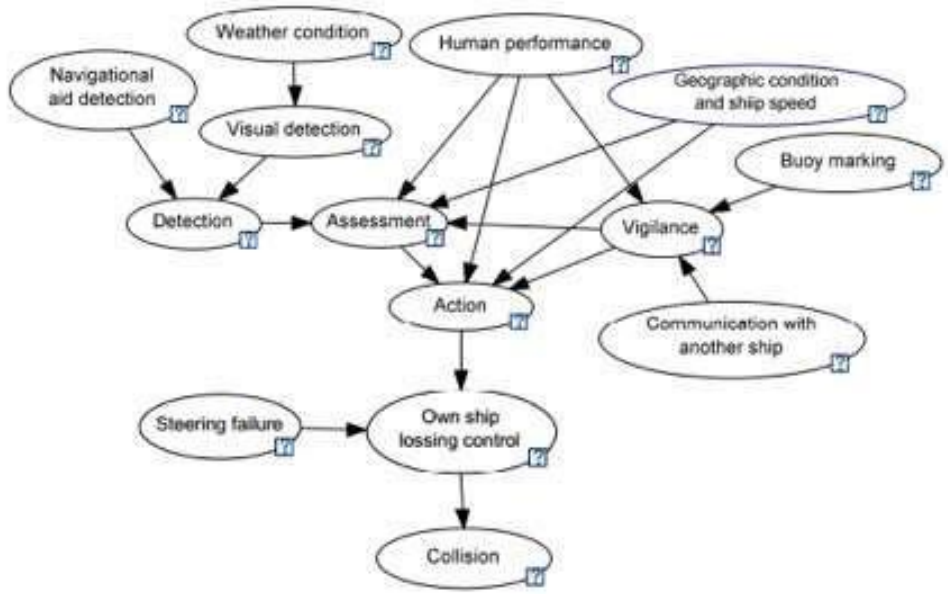

Gambar 7 Bayesian Network Model dari Causation Probability untuk Ship-Ship Collision di Teluk Bintuni

\subsubsection{Hasil Frekuensi Ship to Ship Collision}

Frekuensi tabrakan kapal dengan kapal pada alur pelayaran di Teluk Bintuni untuk kapal dengan kelas i pada xona z, Na, dihitung dengan persamaan 2. Dengan menggunakan Pc menurut hasil dari model Bayesian Network dan berdasarkan data sekunder tentang kapal-kapal yang beroperasi di area tersebut, hasil analisis frekuensi bisa dilihat pada Tabel 1 dan Tabel 2. Kapal-kapal yang melewati Teluk Bintuni rata-rata memiliki kecepatan 6 knots, 8 knots, dan 10 knots. Oleh karena itu t adalah 3 menit untuk kapal dengan kecepatan rendah. Hasil perhitungan ini juga untuk semua tipe rencana alur palayaran . 


\begin{tabular}{|c|c|c|c|c|c|c|c|c|c|c|c|c|c|c|}
\hline \multirow{2}{*}{ Shrip of shrip Cottision } & \multicolumn{3}{|c|}{ Crew boat } & \multicolumn{2}{|c|}{ Supply Vessel } & \multicolumn{3}{|c|}{ LCT/Barge } & \multicolumn{3}{|c|}{ MPSV } & \multicolumn{3}{|c|}{ General Cargo } \\
\hline & 6 knots & 8 knots & 10 knots & 6 knots 8 knots & 10 knots & 6 knots & 8 knots & 10 knots & 6 knots & 8 knots & 10 knots & 6 knots & 8 knots & 10 knots \\
\hline Crew boat & $2.70 \mathrm{E}-06$ & $2.90 \mathrm{E}-06$ & $3.00 \mathrm{E}-06$ & $4.50 \mathrm{E}-06$ 4.70E-06 & $4.80 \mathrm{E}-06$ & $2.90 \mathrm{E}-05$ & $3.10 \mathrm{E}-05$ & $3.20 \mathrm{E}-05$ & $1.20 \mathrm{E}-07$ & $1.30 \mathrm{E}-07$ & $1.30 \mathrm{E}-07$ & $1.10 \mathrm{E}-05$ & $1.10 \mathrm{E}-05$ & $1.10 \mathrm{E}-05$ \\
\hline Supply Vessel & $4.50 \mathrm{E}-06$ & $4.70 \mathrm{E}-06$ & $4.80 \mathrm{E}-06$ & $6.60 \mathrm{E}-066.90 \mathrm{E}-06$ & $7.10 \mathrm{E}-06$ & $3.90 \mathrm{E}-05$ & $4.10 \mathrm{E}-05$ & $4.20 \mathrm{E}-05$ & $1.60 \mathrm{E}-07$ & $1.70 \mathrm{E}-07$ & $1.80 \mathrm{E}-07$ & $1.40 \mathrm{E}-05$ & $1.50 \mathrm{E}-05$ & $1.50 \mathrm{E}-05$ \\
\hline LCT/Barge & $2.90 \mathrm{E}-05$ & $3.10 \mathrm{E}-05$ & $3.20 \mathrm{E}-05$ & $3.90 \mathrm{E}-05 \quad 4.10 \mathrm{E}-05$ & $4.20 \mathrm{E}-05$ & $2.10 \mathrm{E}-04$ & - $2.20 \mathrm{E}-04$ & $2.20 \mathrm{E}-04$ & $9.00 \mathrm{E}-07$ & $9.50 \mathrm{E}-07$ & $9.70 \mathrm{E}-07$ & $7.20 \mathrm{E}-05$ & $7.50 \mathrm{E}-05$ & $7.70 \mathrm{E}-05$ \\
\hline MPSV & $1.20 \mathrm{E}-07$ & $1.30 \mathrm{E}-07$ & $1.30 \mathrm{E}-07$ & $1.60 \mathrm{E}-071.70 \mathrm{E}-07$ & $1.80 \mathrm{E}-07$ & $9.00 \mathrm{E}-07$ & $9.50 \mathrm{E}-07$ & $9.70 \mathrm{E}-07$ & $3.90 \mathrm{E}-09$ & $4.10 \mathrm{E}-09$ & 4.20E-09 & $3.10 \mathrm{E}-07$ & $3.20 \mathrm{E}-07$ & $3.30 \mathrm{E}-07$ \\
\hline General Cargo & $1.10 \mathrm{E}-05$ & $1.10 \mathrm{E}-05$ & $1.10 \mathrm{E}-05$ & $1.40 \mathrm{E}-051.50 \mathrm{E}-05$ & $1.50 \mathrm{E}-05$ & $7.20 \mathrm{E}-05$ & $7.50 \mathrm{E}-05$ & $7.70 \mathrm{E}-05$ & $3.10 \mathrm{E}-07$ & $3.20 \mathrm{E}-07$ & 3.30E-07 & $2.30 \mathrm{E}-05$ & $2.50 \mathrm{E}-05$ & $2.50 \mathrm{E}-05$ \\
\hline
\end{tabular}

Tabel 2 Frekuensi Ship to ship collision (Ns) pada Turn shipping lane dan Kecepatan Kapal 6 knots; 8 knots; dan 10 knots

\begin{tabular}{|c|c|c|c|c|c|c|c|c|c|c|c|c|c|c|c|}
\hline \multirow{2}{*}{ Ship of ship Collision } & \multicolumn{3}{|c|}{ Crew boat } & \multicolumn{3}{|c|}{ Supply Vessel } & \multicolumn{3}{|c|}{ LCT/Barge } & \multicolumn{3}{|c|}{ MPSV } & \multicolumn{3}{|c|}{ General Cargo } \\
\hline & 6 knots & 8 knots & 10 knots & 6 knots & 8 knots & 10 knots & 6 knots & 8 knots & 10 knots & 6 knots & 8 knots & 10 knots & 6 knots & 8 knots & 10 knots \\
\hline Crew boat & $5.20 \mathrm{E}-06$ & $5.40 \mathrm{E}-06$ & $5.60 \mathrm{E}-06$ & $8.50 \mathrm{E}-06$ & $8.70 \mathrm{E}-06$ & $9.10 \mathrm{E}-06$ & $5.60 \mathrm{E}-05$ & $5.70 \mathrm{E}-05$ & $6.00 \mathrm{E}-05$ & $2.30 \mathrm{E}-07$ & $2.30 \mathrm{E}-07$ & $2.40 \mathrm{E}-07$ & $2.00 \mathrm{E}-05$ & $2.10 \mathrm{E}-05$ & $2.20 \mathrm{E}-05$ \\
\hline Supply Vessel & $8.50 \mathrm{E}-06$ & $8.70 \mathrm{E}-06$ & $9.10 \mathrm{E}-06$ & $1.30 \mathrm{E}-05$ & $1.30 \mathrm{E}-05$ & $1.30 \mathrm{E}-05$ & $7.50 \mathrm{E}-05$ & $7.60 \mathrm{E}-05$ & $8.00 \mathrm{E}-05$ & $3.10 \mathrm{E}-07$ & $3.20 \mathrm{E}-07$ & $3.40 \mathrm{E}-07$ & $2.60 \mathrm{E}-05$ & $2.70 \mathrm{E}-05$ & $2.80 \mathrm{E}-05$ \\
\hline LCT/Barge & $5.60 \mathrm{E}-05$ & $5.70 \mathrm{E}-05$ & $6.00 \mathrm{E}-05$ & $7.50 \mathrm{E}-\mathrm{C}$ & $7.60 \mathrm{E}-05$ & $8.00 \mathrm{E}-05$ & $4.00 \mathrm{E}-04$ & $4.10 \mathrm{E}-04$ & $4.20 \mathrm{E}-04$ & $1.70 \mathrm{E}-06$ & $1.80 \mathrm{E}-06$ & $1.80 \mathrm{E}-06$ & $1.40 \mathrm{E}$ & 04 & $1.50 \mathrm{E}-04$ \\
\hline MPSV & $2.30 \mathrm{E}-07$ & $2.30 \mathrm{E}-07$ & $2.40 \mathrm{E}-07$ & $3.10 \mathrm{E}-$ & $0 \mathrm{E}-07$ & $3.40 \mathrm{E}-07$ & $1.70 \mathrm{E}-06$ & $1.80 \mathrm{E}-06$ & $1.80 \mathrm{E}-06$ & $7.30 \mathrm{E}$ & $7.50 \mathrm{E}-09$ & 7.90E-09 & $5.90 \mathrm{E}$ & 07 & $6.30 \mathrm{E}-07$ \\
\hline General Cargo & $2.00 \mathrm{E}-05$ & $2.10 \mathrm{E}-05$ & $2.20 \mathrm{E}-05$ & $2.60 \mathrm{E}-05$ & $2.70 \mathrm{E}-05$ & $2.80 \mathrm{E}-05$ & $1.40 \mathrm{E}-04$ & $1.40 \mathrm{E}-04$ & $1.50 \mathrm{E}-04$ & $5.90 \mathrm{E}-07$ & $6.00 \mathrm{E}-07$ & $6.30 \mathrm{E}-07$ & $4.50 \mathrm{E}-05$ & $4.60 \mathrm{E}-05$ & $4.80 \mathrm{E}-05$ \\
\hline
\end{tabular}

Berdasarkan Tabel 1 dan Tabel 2 diatas, frekuensi kapal yang paling banyak melewati alur tersebut yakni tipe general cargo memiliki nilai frekuensi yang berada di level 3 yakni remote ranking $\left(x<10^{-3}\right)$ sesuai dengan regulasi IMO Formal Risk Assessment (2002). Oleh karena itu, seluruh alur aman terhadap ship-to-ship collision untuk semua tipe kapal.

\subsubsection{Hasil Frekuensi Tubrukan Kapal dengan Platform (Powered Vessel Collision)}

Pada analisis frekuensi ini, model diasumsikan bahwa semua kapal yang telah beroperasi di area tersebut memiliki peluang untuk menabrak paltform. Analisis frekuensi dilakukan untuk masing-masing tipe kapal lalu kumulatif untuk semua tipe kapal. Dari hasil perhitungan, frekuensi per tahun untuk Barge 1638/LCT akan manabrak platform jika platform terletak kurang dari $300 \mathrm{~m}$ dari tengah alur pelayaran. Tabel 3 menunjukkan bahwa jarak aman antara tengah alur dengan platform adalah sekitar $500 \mathrm{~m}$. Untuk ketiga alternatif skema alur pelayaran yang direncanakan, jarak terdekat antara platform dengan tengah alur adalah sekitar $1750 \mathrm{~m}$. Oleh karena itu, dengan memperkirakan data jumlah kapal di masa mendatang, alur pelayaran yang direncanakan harus mempertimbangkan keselamatan kapal dengan nilai frekuensi tabrakan tiap tahun kurang dari satu $(<1)$.

Tabel 3 Hasil frekuensi kumulatif tabrakan untuk semua kapal yang beroperasi di Teluk Bintuni

\begin{tabular}{|c|c|c|c|c|c|c|c|c|c|c|c|}
\hline \multirow{2}{*}{\multicolumn{2}{|c|}{ Good Visibility }} & \multicolumn{4}{|c|}{ Potential Traffic } & \multirow{2}{*}{\multicolumn{2}{|c|}{ Bad Visibility }} & \multicolumn{4}{|c|}{ Potential Traffic } \\
\hline & & 2171 & 4342 & 6513 & 8684 & & & 2171 & 4342 & 6513 & 8684 \\
\hline \multirow{5}{*}{$\begin{array}{l}\text { Fcp (x meter } \\
\text { from working } \\
\text { vessel) }\end{array}$} & 100 & 0,1702 & 0,3404 & 0,5107 & 0,6809 & \multirow{5}{*}{$\begin{array}{c}\text { Fcp (x meter } \\
\text { from } \\
\text { working } \\
\text { vessel) }\end{array}$} & 100 & 0,9183 & 1,8367 & 2,7550 & 3,6733 \\
\hline & 200 & 0,1076 & 0,2152 & 0,3229 & 0,4305 & & 200 & 0,5864 & 1,1727 & 1,7591 & 2,3454 \\
\hline & 300 & 0,0743 & 0,1487 & 0,223 & 0,2973 & & 300 & 0,4053 & 0,8105 & 1,2158 & 1,6211 \\
\hline & 400 & 0,0502 & 0,1003 & 0,1505 & 0,1505 & & 400 & 0,2743 & 0,5486 & 0,8229 & 1,0972 \\
\hline & 500 & 0,0319 & 0,0638 & 0,0957 & 0,1276 & & 500 & 0,1763 & 0,3526 & 0,5289 & 0,7052 \\
\hline
\end{tabular}

\subsubsection{Hasil Frekuensi Tubrukan Kapal dengan Platform (Drifting Vessel Collision)}

Berdasarkan hasil perhitungan frekuensi pertahun untuk tabrakan kapal akibat drifting seperti yang terlihat pada Tabel 4, pada area tersebut diperkirakan untuk masa mendatang, frekuensinya akan kurang dari 1, yakni 0,053. Ini menunjukkan bahwa platform aman terhadap tabrakan dari kapal karena drifting.

Tabel 4 Frekuensi tabrakan kapal dengan platform akibar drifting

\begin{tabular}{cllcc}
\hline No & Notation & \multicolumn{1}{c}{ Input } & Unit & Value \\
\hline 1 & $\mathrm{~N}$ & Number of vessels in area & vessel/year & 2954 \\
2 & $\mathrm{~F}_{\text {dift }}$ & Frequency of breakdown & per hour & $2.0 \mathrm{E}-05$ \\
3 & $\mathrm{~T}$ & Average time spend in area & hours & 36 \\
4 & $\mathrm{P}_{\mathrm{D} 1}$ & Probability of no drift towards platform & - & 0.5 \\
5 & $\mathrm{P}_{\mathrm{D} 2}$ & Probability of no effectuve external assisstance & - & 0.1 \\
6 & $\mathrm{P}_{\mathrm{D} 3}$ & Probability of no collision avoidance by the ship & - & 0.5 \\
\hline $\mathbf{7}$ & $\mathrm{F}_{\mathrm{CD}}$ & Annual frequency of collision due to drifting & collision/year & $\mathbf{0 . 0 5 3}$ \\
\hline
\end{tabular}

\section{KESIMPULAN}


Berdasarkan frekuensi tabrakan dengan tipe head-on antara kapal ke platform, jarak aman antara tengah alur dengan platform adalah sekitar $500 \mathrm{~m}$. Karena jarak terdekat tengah alur yang direncanakan saat ini adalah $1750 \mathrm{~m}$, maka di masa mendatang, alur ini masih aman untuk dilewati kapal-kapal karena frekuensinya kurang dari satu (<1). Alur pelayaran yang direncanakan juga mempertimbangkan keselamatan kapal-kapal yang melewatinya dari tubrukan akibat drifting karena nilai frekuensinya juga kurang dari satu $(<1)$.

\section{DAFTAR PUSTAKA}

[1] T. \& W. MULYADI, Y., KOBAYASHI, E., WAKABAYASHI, N., PITANA, "Development of ship sinking frequency model over Subsea Pipeline for Madura Strait using AIS data," WMU J. Marit. Aff., vol. 13, pp. 43-59, 2014.

[2] P. F. HANSEN, IWRAP MK II : Basic Modelling Principles for Prediction of Collision and Grounding Frequencies. Technical University of Denmark, 2007.

[3] J. Spouge, "A Guide To Quantitative Risk Assessment for Offshore Installations.” 